\title{
1 First report of Theileria annulata in Nigeria: findings from cattle ticks in Zamfara and
}

\section{Sokoto States}

3 Adamu Haruna Mamman ${ }^{1,2^{*}}$, Vincenzo Lorusso ${ }^{1,3^{*}}$, Babagana Mohammed Adam ${ }^{1}$, Abraham

4 Goni Dogo ${ }^{3}$, Kevin J Bown ${ }^{1}$, Richard J Birtles ${ }^{1 \S}$

5 Authors' Affiliation:

$6{ }^{1}$ School of Science, Engineering and Environment, The University of Salford, Greater

7 Manchester, M5 4WT, United Kingdom.

$8{ }^{2}$ Department of Veterinary Parasitology and Entomology, Faculty of Veterinary Medicine,

9 University of Jos, Jos, Plateau State, Nigeria.

$10{ }^{3}$ Global Research \& Intellectual Property Division, Vetoquinol, Paris France

13 *These authors contributed equally to this article.

$15{ }^{\S}$ Corresponding Author:

16 Prof Richard Birtles

17 Email: r.j.birtles@salford.ac.uk 


\section{Abstract}

\section{Background}

26 Ticks and tick-borne pathogens (TBPs) represent a significant economic burden to cattle

27 farming in sub-Saharan Africa including Nigeria. However, in the northern part of this

28 country, where the largest livestock population reside, little is known about the contemporary

29 diversity of ticks and TBPs. This area is particularly vulnerable to climate change, undergoing

30 marked transformation of habitat and associated flora and fauna that is also likely to include

31 ticks. This study aimed to document the occurrence of tick species and Apicomplexan TBPs

32 in cattle from North-Western Nigeria.

\section{Methods}

34 In 2017, ticks were collected from cattle in Zamfara and Sokoto States and identified

35 morphologically. Additionally, a subset of ticks were screened molecularly for the detection

36 of Apicomplexan DNA.

\section{Results}

38 A total of 494 adult ticks were collected from 80 cattle in Zamfara and 65 cattle in Sokoto

39 State. Nine tick species were encountered, including seven Hyalomma spp. (i.e. Hyalomma

40 dromedarii, Hyalomma impeltatum, Hyalomma impressum, Hyalomma marginatum,

41 Hyalomma rufipes, Hyalomma truncatum and Hyalomma turanicum), Amblyomma

42 variegatum and Rhipicephalus (Boophilus) decoloratus. All species were present in Zamfara,

43 whereas only five species were found in Sokoto. Hyalomma rufipes was the most prevalent

44 tick infesting cattle in Zamfara State (76.2\%), while H. dromedarii was the most prevalent in

45 Sokoto State (43.7\%), confirming the widespread transfer of this species from camels onto

46 livestock and its adaptation to cattle in the region.

47 Of 159 ticks screened, 2 out of 54 (3.7\%) from Zamfara State and 29 out of 105 (27.6\%) from

48 Sokoto State harboured DNA of Theileria annulata, the agent of tropical theileriosis. 


\section{Conclusions}

50 This study confirms the presence of a broad diversity of tick species in cattle from North-

51 Western Nigeria, providing the first locality records for Zamfara State. The occurrence of $H$.

52 turanicum, recorded for the first time in Nigeria, indicates a distribution of this tick beyond

53 Northern Africa.

54 This study provides the first report for T. annulata in Nigeria. Given its enormous burden on

55 livestock farming in North Africa and across Asia, further investigations are needed to better

56 understand its epidemiology, vector transmission and potential clinical significance in cattle

57 from Northern Nigeria and neighbouring Sahelian countries.

59 Keywords: Ticks, Cattle, Tick-borne pathogens, Tick-borne diseases, Theileria spp.,

60 Piroplasms, Livestock, Nigeria, Africa

61

62

63

64

65

66

67

68 


\section{Background}

70 Ticks represent a significant economic burden to cattle farming and, overall, the development

71 of the livestock sector in sub-Saharan Africa (SSA) [1, 2, 3]. Their significance is due to the

72 impairment they cause to livestock productivity, attributable to both the direct and indirect

73 effects of tick's parasitism and blood feeding [2]. In cattle, direct damage caused by ticks

74 include anaemia, stress ('tick worry'), reduction of feeding thus decrease of weight gain and

75 milk yields, susceptibility to secondary infections, devaluation of hide quality,

76 hypersensitivity and toxicosis $[1,2]$. Indirect adverse consequences of tick infestation in cattle

77 are linked to the conditions that are caused by the plethora of tick-borne pathogens (TBPs),

78 including mostly protozoa and bacteria, but also helminths, viruses and fungi, some of which

79 are of zoonotic importance [1-4]. The most important TBPs threatening cattle health and

80 productivity in SSA are the causative agents of theileriosis (i.e. the 'East Coast fever' agent

81 Theileria parva; Theileria annulata; Theileria mutans and Theileria velifera), babesiosis (i.e.

82 Babesia bigemina and Babesia bovis), anaplasmosis (i.e. Anaplasma marginale, Anaplasma

83 centrale and Anaplasma bovis) and ehrlichiosis (i.e. the 'heartwater' agent Ehrlichia

84 ruminantium) [1].

85 In spite of the enormous burden of ticks and TBPs on livestock farming, for many parts of

86 SSA, even fundamental epidemiological information is lacking. Nigeria is a case in point;

87 despite one of the largest cattle populations in the continent (of approximately 20 million

88 heads) [5], contributing one third of national agricultural GDP and providing $36.5 \%$ of the

89 total protein intake of Nigerians [6], substantial gaps affect the current understanding of the

90 epidemiology of ticks and TBPs in the country [7], with knowledge of cattle-associated tick

91 diversity and distribution being rather patchy [8-12] when not outdated [13-16]. Additionally,

92 although approximately $90 \%$ of the country's cattle population is concentrated in the Northern

93 region $[6,17]$, most historical surveys were carried out in southern States $[13,18]$. So far, 
94 published investigations on cattle ticks from Northern Nigeria have focused on limited areas

95 of eastern (e.g. Maiduguri and Yobe State) [10-11], or western States (e.g. Sokoto and Kebbi

96 States) [19-22], limiting in some instances the identification of ticks to the genus level [10,

97 11, 20]. Similarly, the majority of studies on TBPs in Nigeria, detecting the presence of

98 apicomplexan parasites belonging to the genera Theileria and Babesia, and members of the

99 bacterial genera Anaplasma, Ehrlichia, Rickettsia and Coxiella spp., have mostly relied on

100 cytological (i.e. microscopical examination of blood smears and biopsies) [23-28] and

101 serological approaches (e.g. ELISA and immunofluorescence assays) [26, 29-32], and only in

102 a few, recent instances on the molecular screening of bovine blood [33-35] and ticks [36, 37].

103 Moreover, to date no study based on molecular diagnostic techniques has ever been carried

104 out in the North-Western region.

105 The epidemiological importance of surveying ticks and TBPs in cattle from Northern Nigeria

106 is also enhanced by the frequent movement and introduction in this region of livestock hailing

107 from neighbouring countries like Niger, Chad and Cameroon, brought to Nigeria to be sold in

108 more profitable local markets [38]. Furthermore, the heavy reliance on climate-sensitive

109 economic activities, such as agriculture and livestock keeping, makes Northern Nigeria

110 particularly vulnerable to climate change [39]. Spanning the Sudano-Sahelian ecological zone

$111[40,41]$, this region is currently experiencing a combination of rising heat and declining

112 rainfall that together are accelerating desert encroachment and marked habitat change $[39,42$,

113 43]. Besides affecting cattle health directly through their effects on water and pasture

114 availability, these alterations may also lead to indirect negative consequences, linked to the

115 likely changes that they will cause on tick populations' diversity and ecology [44]. Habitat

116 changes may indeed compromise the fitness of some endemic tick species and create new

117 niches exploitable by exotic species, originating from Sahelian and North African countries,

118 adapted to hot and dry environments. The arrival of such species may well be accompanied by 
119 the TBPs they vector.

120 The present study aimed therefore to determine the contemporary diversity of cattle-

121 associated ticks and apicomplexan TBPs in a region of North-Western Nigeria heavily reliant

122 on cattle keeping and significantly affected by climate change $[43,45,46]$, with the objective

123 of assessing the extent of change that maybe be attributed to the latter's impact.

125 Methods

126 Study area

127 Field activities were carried out between March and May 2017, in two north-western States of

128 Nigeria, namely Zamfara and Sokoto, where a convenience sample of cattle were inspected

129 and surveyed for tick infestations. In Zamfara, ticks were collected from cattle in the villages

130 of Anka, Kwaye, Kwakwalwa, Gema and Abara, all of which lie within the Anka Local

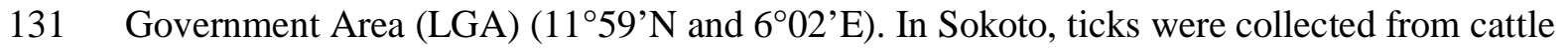

132 in cattle markets from three LGAs, namely Sokoto North, Wurno, and Illela $\left(13^{\circ} 03^{\prime} \mathrm{N}\right.$ and $5^{\circ}$

133 14'E) (Table 1).

134 Both Sokoto and Zamfara are among the poorest States of the Federal Republic of Nigeria

135 [47]. Their economy is almost entirely reliant on agriculture. Livestock including cattle, sheep

136 and goats are reared, and some crops are grown. Donkeys and camels are commonly used as

137 draft animals [45, 48].

138 The region lies on the boundary of Sudan savanna and Sahel climatic zones [41]. The

139 meteorology is seasonal, with a 3-4 month wet season occurring between June and

140 September, during which time about $500 \mathrm{~mm}$ of rain falls. The remainder of the year is very

141 dry. Average daily temperatures range between about $18{ }^{\circ} \mathrm{C}$ and $38{ }^{\circ} \mathrm{C}$. The vegetation is

142 characterised as open savanna grasslands or open savanna woodland, with fine-leaved and

143 broad-leaved trees and shrubs, which are deciduous for several weeks [49]. 


\section{Tick collection and identification}

146 Each animal sampled was restrained by its owner/herder and its hide examined carefully,

147 focusing in particular on established predilection sites for tick attachment (i.e. ear, dewlap,

148 abdomen, hooves, inguen, perineum, peri-anal region, tail) [8, 50]. From these anatomical

149 regions, all visible adult ticks were collected using steel forceps to remove each specimen in

150 its entirety. Immediately after collection, all ticks removed from the same individual cattle

151 were placed in a $5 \mathrm{ml}$ plastic tube containing $70 \%$ ethanol, before being transported to the

152 University of Salford for further analysis. Once in the laboratory, all collected ticks were

153 identified to the species level on the basis of observed anatomical features, using the

154 taxonomical keys by Walker et al. [51].

\section{Detection and identification of Apicomplexa using molecular methods}

156 A subset of collected ticks ( $\mathrm{n}=159,32.2 \%$ of total ticks) were screened for apicomplexan

157 pathogens using molecular methods. These ticks were chosen to embrace all species

158 encountered and the different locations in which each tick species was encountered (Table 3)

159 Crude DNA extracts, prepared from individual ticks as previously described [52], were

160 incorporated into a previously described PCR targeting an 18S rDNA fragment specific to

161 apicomplexan taxa [53]. PCRs were prepared in a dedicated DNA-free laboratory. "Blanks"

162 (PCRs containing water instead of DNA extracts) were co-processed with all samples at a

163 ratio of 5 samples:1 blank, to test for cross-contamination. Reagent controls (a DNA-free

164 negative and a Babesia microti positive) were also included in each set PCRs prepared.

165 The success of the PCR was assessed by UV visualisation of GelRed-stained amplification

166 products (of about 680 base pairs) following their electrophoretic resolution on a $1 \%(\mathrm{w} / \mathrm{v})$

167 agarose gel. Amplification products were purified using an Isolate II PCR and gel kit

168 according to manufacturer's instructions (Invitrogen, Carslbad, California, USA). Sanger 
169 sequencing of both strands of each PCR product was carried out commercially.

170 Chromatograms obtained were visualised using Chromas Pro software (Technelysium,

171 Brisbane, Australia). Data from complementary strands of each amplicon were aligned with

172 one another and regions of ambiguity together with primer sequences at the extremities were

173 removed. The identity of the organism from which a sequence obtained was determined by

174 comparison with data held on GenBank using Basic Local Alignment Search Tool (BLAST).

\section{Statistical analysis}

176 Data were entered in Microsoft Excel, through which mean tick infestations and standard 177 errors were calculated at the study village, LGA and State (i.e. Zamfara and Sokoto State)

178 level (Table 1). For the two States, mean prevalence, including 95\% Confidence Intervals

179 (CI), of tick species retrieved were calculated using the WinPepi software (Version 11.6).

180 Using the same software, cumulative tick counts recorded for each State were compared

181 statistically using the Chi-squared test. In addition, infection rates were compared according

182 to tick species and State of provenance (for both ticks and cattle), using the two-tailed

183 Fisher's exact test. P values $<0.05$ were considered statistically significant.

\section{Results}

\section{Tick identification and infestation burden}

187 In total, 494 adult ticks were collected from 145 cattle; of these 254 off 65 cattle in Sokoto

188 and 240 off 80 cattle in Zamfara (Table 1). The mean infestation rate was 3.0 in Zamfara and

1893.9 in Sokoto, with no statistically significant difference being recorded $(\mathrm{P}=0.8)$ (Table 1). A

190 total of nine tick species were encountered, these included seven Hyalomma species (i.e.

191 Hyalomma dromedarii, Hyalomma impeltatum, Hyalomma impressum, Hyalomma

192 marginatum, Hyalomma rufipes, Hyalomma truncatum and Hyalomma turanicum), 
194 nine species were present in Zamfara and these included H. turanicum (Figure 1.VII, a-b),

195 recorded for the first time in Nigeria. Only five species were present in Sokoto, namely (from

196 the most to the least prevalent) H. dromedarii, H. impeltatum, H. truncatum, H. impressum

197 and H. rufipes (Table 2). However, these corresponded to five of the six most abundant

198 species collected in Zamfara, with only those species for which only a single specimen was

199 found (i.e. H. marginatum, H. turanicum and Rh. (Bo.) decoloratus) and A. variegatum being

200 absent (Table 2).

201 There was a marked difference between the relative abundance of tick species in each State.

202 In Zamfara, H. rufipes dominated (76.2\%), with no other species accounting for more than

$2038 \%$ of samples. Conversely, in Sokoto, H. dromedarii was most abundant (43.7\%) and,

204 together with $H$. impeltatum, accounted for $80 \%$ of the ticks collected (Table 2). Hyalomma

205 rufipes was present in Sokoto, but at a relative prevalence of only 3.1\%, whereas $H$.

206 dromedarii was present in Zamfara, but only at a relative prevalence of $2.5 \%$ (Table 2).

207 Overall 261 male ticks and 233 female ticks were collected. The ratio of male to female ticks

208 was very different in the two States, being 2.6:1 in Zamfara and 1:1.9 on Sokoto (Table 2).

210 Molecular screening

211 Out of the total of 159 ticks screened molecularly, 31 ticks (19.5\%) were found positive for

212 Apicomplexan DNA, with all bar two being ticks from Sokoto (Table 3). Significantly more

213 ticks from Sokoto (29/105 tested, 27.6\%) yielded a PCR product than ticks from Zamfara

$214(2 / 54,3.7 \%)(\mathrm{P}<0.001)$ and significantly more cattle from Sokoto $(18 / 35$ tested, 51.4\%) bore

215 infected ticks than cattle from Zamfara $(2 / 35$ tested, 5.7\%) $(\mathrm{P}<0.001)$.

216 Unambiguous sequence data were obtained from 23 of the amplicons, including those

217 obtained from the two positive ticks from Zamfara. BLAST analysis of these sequences (609 
218 base pairs) revealed all to be indistinguishable from one another and to share $100 \%$ similarity

219 with partial 18S rDNA sequences of many strains of Theileria annulata (e.g. GenBank

220 MN944852). The 18S rDNA sequence obtained shared less than 99.4\% similarity with those

221 from other Theileria species (most similar was 4 SNPs compared to Theileria lestoquardi $18 \mathrm{~S}$

222 rDNA, GenBank AF081135). A selected sequence amongst those obtained was deposited in

223 GenBank on 30 October 2020 (GenBank MW191850).

224 Tick species containing T. annulata DNA included mainly H. dromedarii and H. impeltatum,

225 but also H. truncatum, H. impressum and H. rufipes (i.e. all species encountered in Sokoto)

226 (Table 3).

227 The prevalence of infection in each tick species present in Sokoto did not vary significantly

228 ( $\mathrm{P}=0.6$ ), ranging from $14.3 \%$ in $H$. impressum to $50 \%$ in H. truncatum (Table 3). The large

229 majority $(\mathrm{n}=27 / 31 ; 87.1 \%)$ of PCR positive ticks were females, assessed as being either

230 partially $(n=16)$ or very engorged $(n=11)$ (data not shown). However, four PCR positive ticks

231 were male, one of which (i.e. H. dromedarii) appeared to be unfed.

233 Discussion

234 All cattle surveyed in this study were infested by adult ticks, in both Zamfara and Sokoto

235 States. The generally relatively low degree of infestation, which did not differ significantly

236 between the two States, could be the outcome of (i) the time of the year when the sampling

237 took place (i.e. late dry season, when most tick populations are expected to be less abundant

238 than in the wet season) and (ii) the traditional control practice based on manual removal of

239 ticks, adopted periodically (e.g. once a week) by cattle keepers [8].

240 The rich diversity of tick species parasitising cattle encountered in this survey is generally in

241 keeping with contemporary reports in Nigeria [8,9]. As expected for sites in the Sahel, 
242 Hyalomma species dominated [51, 54-57]. While it represents the first investigation of this

243 kind for the State of Zamfara, this study confirms the occurrence of five Hyalomma spp. (i.e.

244 H. dromedarii, H. impeltatum, H. impressum and H. trunctatum) which were previously

245 recorded, although in different prevalences, by two surveys carried out on cattle in Sokoto

$246[19,21]$.

247 The presence of such a high relative prevalence of $H$. dromedarii is remarkable. Commonly

248 known as 'the camel Hyalomma', this tick has a wide distribution in Africa, encompassing

249 arid and desertic regions that are north of the equator, where it is the predominant species

250 parasitising camels [51]. Numerous previous reports demonstrate its ability to infest several

251 hosts including cattle, but not with the relative success observed in this study [54, 58]. In

252 Sokoto, H. dromedarii was the most frequently encountered tick, accounting for almost half

253 the total number of collected ticks (43.7\%), suggesting frequent transfer of ticks from camels

254 to cattle and/or that $H$. dromedarii has adapted itself to parasitise cattle here to a degree not

255 reported elsewhere in its range. The presence of $H$. dromedarii on cattle in the absence of

256 (frequent) camel contact has indeed been noted previously but only at very low infestation

257 rates [59]. Our findings are in general agreement with those from two previous surveys

258 carried out on cattle from Sokoto, in 2009-10 [19] and 2013 [21], recording H. dromedarii as

259 the second the most prevalent tick species (13.3\% and $15.4 \%$, respectively), in both cases

260 after $H$. truncatum (15.5\% and $18.4 \%$, respectively) $[19,21]$. Nonetheless, the remarkably

261 higher prevalence documented by the present investigation may be suggestive of adaptation of

262 H. dromedarii towards parasitising cattle which may have occurred in recent times in Sokoto

263 State. Further investigations aiming to verify this hypothesis and assess the potential

264 implication of ecological and climatic factors, would be advisable.

265 Our observation of the dominance of H. dromedarii on cattle in Sokoto mirrors the findings

266 by Lawal et al. [56] and Onyiche et al. [57], reporting H. dromedarii as the most prevalent 
$267(46.9 \%)[56]$ and the second most prevalent (42.3\%) [57] tick species collected in camels

268 from Sokoto. Interestingly, in the very recent survey by Onyiche et al. [57], specimens of $H$.

269 dromedarii tested positive for the presence of DNA of the Q fever agent Coxiella burnetii.

270 The fact that the dominance of $H$. dromedarii on cattle was not also observed in Zamfara

271 suggests that the ecological niche it currently occupies in Sokoto does not extend southward

272 within the Sudan savanna of Nigeria and could also be attributable to Zamfara's smaller

273 camel population compared to Sokoto [59].

274 In Zamfara, H. rufipes was by far the most abundant tick encountered. This species is the

275 most widespread member of the genus present in Africa and its major contribution to cattle-

276 associated tick fauna has been reported at several sites across this range [55, 60, 61]. It was

277 previously identified in cattle from North-Central (i.e. Plateau State) [8, 9], North-Eastern (i.e.

278 Taraba and Borno States) and North-Western Nigeria (i.e. Kaduna, Kano, Katsina and

279 Sokoto States) $[9,19,21]$. Its veterinary importance is linked to its capacity to act as vector of

280 Anaplasma marginale [62] and Babesia occultans [63]. It is also recognised as an important

281 vector Crimean-Congo haemorrhagic fever (CCHF) virus to humans [51]. Importantly,

282 specimens of $H$. rufipes collected from camels at slaughterhouses in Kano State, were

283 previously found positive for DNA of Rickettsia aeschlimannii, responsible for a zoonotic

284 spotted fever [66].

285 Hyalomma impeltatum was the second most prevalent tick species $(n=93 / 254 ; 36.6 \%)$ in

286 Sokoto State; this tick was found in more modest numbers in Zamfara State ( $n=14 / 240$;

$2875.8 \%$ ). Commonly infesting camels in Northern Nigeria [56, 64], this species was also

288 documented in trade cattle that reached Ibadan, South-Western Nigeria, hailing from the

289 North of the country or neighbouring Chad or Niger [27] as well as in cattle from Sokoto

290 State $[19,21]$. The prevalence of $H$. impeltatum recorded by this survey in Sokoto (i.e.

$29136.4 \%)$ was higher than that previously documented in cattle from the same State $(10.1 \%$ and 
$2929.4 \%$, respectively) $[19,21]$, confirming the adaptability of this species to parasitising cattle

293 in areas of sympatry with camels. Like for H. rufipes, specimens of H. impeltatum collected

294 from camels in Kano State were found to harbour DNA of the zoonotic R. aeschlimannii [64].

295 In this study, specimens of $H$. truncatum were recorded in cattle from both Zamfara and

296 Sokoto State (Table 2). This tick is known for commonly infesting cattle in Nigeria $[8,9,15$,

$29716,19,21]$; its significance is mostly related to its capacity to cause a toxic syndrome

298 ('sweating sickness'), particularly in young cattle [65] and to the injuries caused by its long

299 mouthparts, especially in the interdigital clefts [51]. Like H. dromedarii, H. truncatum

300 specimens collected from camels from Northern Nigeria (i.e. Sokoto, Kano and Jigawa

301 States) were found to harbour C. burnetii DNA [57].

302 This study confirms the occurrence of $H$. impressum in North-Western Nigeria. Initially

303 documented in trade in Ibadan [27], this tick was previously described in cattle from Sokoto

304 State $[19,21]$. The fact that $H$. impressum was encountered on cattle in this study but not in

305 the two aforementioned surveys on camels from Sokoto $[56,57]$ may reflect a stronger host-

306 specificity for cattle, although this conclusion is confounded by the low relative abundance of

307 this species on the cattle we observed. Moreover, specimens identified as H. impressum were

308 also encountered in camels in Kano State [56, 64]. Very little is known about the veterinary

309 importance and vectorial competence of this tick species, although some engorged specimens

310 in Ibadan showed to harbour kinetes of 'Babesia spp.' [27].

311 One male specimen of $H$. marginatum was identified in cattle from Zamfara State. It was

312 morphologically distinguished from the closely related H. rufipes, especially on the basis of

313 the distinctive pattern of grooves on its conscutum. Usually reported in livestock across the

314 Maghreb region, Egypt, Sudan and Ethiopia [51], the occurrence of this tick species may be

315 more common that known until now in the Sahel region. In Nigeria, this tick was previously

316 detected in trade cattle probably introduced from neighbouring Chad or Niger [27]. It is 
317 however thought of being unable to survive under desert conditions [50], which may explain

318 its absence from cattle surveyed in Sokoto State, in this study as well as in previous ones [19,

31921 ] and suggest that it may be more prevalent during the wet season months. Like H. rufipes,

320 it can be a vector of the zoonotic CCHF virus [51].

321 Perhaps the most noteworthy encounter among cattle-associated ticks in Zamfara was $H$.

322 turanicum. This species has, to our knowledge, not been reported in Nigeria, or elsewhere in

323 West Africa previously. It is thought to be endemic in the north-east of the continent, and is

324 established in arid, hot parts of southern Africa after accidental introduction [51]. This tick is

325 not known to transmit pathogens to livestock, although it is considered a vector of the CCHF

326 virus to humans [51]. Hyalomma turanicum has a two-host life cycle, with adults typically

327 parasitising wild and domesticated large ruminants and larvae and nymphs feeding on smaller

328 mammals and ground-frequenting birds [51]. The tick has also been reported in Europe,

329 associated with migratory birds using the western European-African flyway [66]. As this

330 flyway embraces Nigeria and large parts of Africa north of the Sahara, it is reasonable to

331 propose that the $H$. turanicum observed in Zamfara was introduced as a feeding nymph by a

332 migratory bird. As yet to it too early to conjecture if $H$. turanicum is established in Northern

333 Nigeria; further surveys of cattle and likely hosts of immature life-stages would help clarify

334 this uncertainty. Considering the suitability of this tick species for desert and steppe

335 landscapes [51], climate change-induced desert encroachment in the Sahelian region may

336 potentially favour the establishment of $H$. turanicum in Northern Nigeria.

337 A few ( $\mathrm{n}=7)$, all male specimens of $A$. variegatum were recorded in cattle from Zamfara. The

338 low numbers of $A$. variegatum recorded in Zamfara, coupled with its absence from cattle from

339 Sokoto State, may be due to the fact that the sampling took place during the late dry season,

340 while the adult population of this tick species tends to peak during the wet season.

341 Accordingly, this tick was previously documented in cattle from Sokoto, surveyed between 
342 January and December [19] and February and July [21]. This species is indeed known to be

343 widespread across Nigeria [8, 9, 16, 19, 21], being responsible for the transmission of several

344 bovine TBPs such as E. ruminantium, Dermatophilus congolensis, T. mutans and T. velifera

345 (reviewed in [8]). In this study, however, none of the three A. variegatum specimens screened

346 was positive for Apicomplexan DNA.

347 One (female) specimen of Rh. (Bo.) decoloratus was also collected from a cow from Zamfara

348 State. Known as the vector of B. bigemina, A. marginale and A. centrale [23], this species is

349 considered the most prevalent boophilid tick infesting cattle in North-Central Nigeria [8, 13].

350 As for A. variegatum, its low abundance can be due to the seasonality of this tick, peaking

351 during the wet season $[8,16]$, rather than when this survey took place.

352 Rhipicephalus (Boophilus) microplus was not recorded in any of the cattle sampled in this

353 study, suggesting that the spread of this invasive tick, likely introduced in Nigeria through

354 cattle from Benin [9] and so far identified in North-Eastern (i.e. Borno, Taraba and Yobe

355 States) [9-11], North-Central (i.e. Kwara State) [9], South-Eastern (i.e. Enugu State) [12] and

356 South-Western Nigeria (i.e. Ogun and Ondo States) [9], has probably not reached the North-

357 West of the country. In Nigeria, indeed, this tick species can be expected to occur mostly in

358 the southern regions, with higher relative humidity and annual precipitation compared to the

359 drier northern States [9].

360 The preponderance of male rather than female specimens for most tick species collected in

361 cattle from Zamfara State is an accordance with the existing literature (reviewed in [8]).

362 Female ticks are indeed more frequently groomed off by cattle and tend to parasitise them for

363 shorter periods compared to adult males [8]. The detection of more female than male

364 specimens among the ticks collected in Sokoto State can be attributed to the context where the

365 sampling took place. With sampling sites being rather crowded cattle markets, it is possible

366 that our collection may have somehow privileged female ticks, that are indeed more 
367 conspicuous thus more easily identifiable with the naked eye, than male ones.

368 This study provides the first report of T. annulata in Nigeria. Tropical theileriosis is

369 recognised as one of the most economically important diseases of livestock across North

370 Africa and much of Asia [67], and its presence in SSA, where livestock productivity is

371 already severely compromised by endemic parasites and pathogens [3], is an additional

372 concern. In Africa, T. annulata has so far been detected in eight countries, mostly in the

373 northern (i.e. Morocco, Algeria, Tunisia and Egypt) and eastern part of the continent (i.e.

374 Sudan, South Sudan and Ethiopia) [67], with only Mauritania accounting for the locality

375 records reported so far for West Africa [67-70].

376 Our detection of $T$. annulata DNA in ticks collected off 18 (of 35 tested) cattle in three

377 different markets in Sokoto as well as off two (of seven tested) cattle in one village in

378 Zamfara suggests it may be established in North-Western Nigeria. Considering that a

379 significantly greater proportion of ticks and cattle from Sokoto contained T. annulata DNA

380 than in Zamfara, it is likely that the parasite is more prevalent in the former State. That

381 Sokoto is a likely port of introduction, be it recent or not, and circulation of this pathogen, is

382 not unexpected. The State of Sokoto is indeed a major centre for livestock (including camels)

383 trade in the region, attracting farmers and pastoralists not just from North-Western Nigeria,

384 but also from neighbouring Niger and further afield in the Sahel and Saharan regions [71, 27].

385 The importance of trans-border trade as routes of entry of exotic ticks and TBPs into Nigeria

386 has been established in the South-West of the country [72], with no information being

387 available for the North of the country. Further characterisation of the T. annulata populations

388 detected in Sokoto using, for example, previously described polymorphic markers [73] and

389 comparison of these data with those obtained elsewhere in the parasite's range, may help

390 pinpoint their provenance.

391 It is currently unclear if $T$. annulata has been long-established in North-Western Nigeria or if 
392 it is a recent arrival. Indeed, that tropical theileriosis has not been reported before in Nigeria

393 may reflect absence or a low awareness of it as a clinically apparent disease. The latter may

394 also have resulted from endemic stability in the region coupled with low susceptibility of

395 local cattle breeds to clinical disease, as reported elsewhere [74, 75]. Similarly, surveys

396 carried out in cattle Mauritania, during the wet and the dry seasons, did not reveal any clinical

397 case [69], with Zebus in the southern part of the country being found to have high specific

398 antibody titres to T. annulata [68]. Nevertheless, a fatal case of bovine theileriosis was

399 reported in a Friesian cow born in a dairy farm in Nouakchott, originally established with

400 cattle imported from France, where H. dromedarii was the only tick species retrieved [68].

401 Surveys of local cattle are therefore urgently required to further exploration of the

402 epidemiology of this infection and assess its clinical importance in cattle reared in North-

403 Western Nigeria and potentially in other neighbouring regions. Importantly, the emergence

404 and spreading of resistance to the most widely used theilericidal compound on the market (i.e.

405 buparvaquone) in T. annulata strains circulating in Northern and Eastern Africa [67], further

406 highlights the need for future epidemiological investigations.

407 Moreover, given that the susceptibility of camels to T. annulata has been established and

408 infections appear common elsewhere [76], they too should be surveyed to explore what role

409 they play in the natural cycle of T. annulata in the area. A small survey of TBPs in camels in

410 Sokoto previously detected Theileria species, but not specifically $T$. annulata [77].

411 In the present study, five tick species were detected positive for $T$. annulata DNA, namely $H$.

412 dromedarii, $H$. impeltatum, $H$. rufipes, $H$. truncatum and $H$. impressum. Of the four

413 Hyalomma species implicated in the transmission of T. annulata in Africa (i.e. H. scupense,

$414 H$. anatolicum, $H$. dromedarii and H. lusitanicum) [67], only H. dromedarii was encountered

415 on cattle in this study, and at far greater abundance in Sokoto than Zamfara. Thus, it can be

416 hypothesised that $H$. domedarii could be the most probable vector of $T$. annulata in North- 
417 Western Nigeria. However, other agro-ecological determinants, such as immature ticks' host

418 availability and husbandry practices may also underlie the inter-State differences we

419 observed. Due to its capacity to withstand very hot and dry habitats, $H$. dromedarii is thought

420 to have a strong comparative advantage over other endemic tick African species, in regions

421 where climate change is expected to enhance the environmental aridity [67]. These

422 characteristics, coupled with the vulnerability to climate change of North-Western Nigeria,

423 may cause an increase of the prevalence of theileriosis in cattle from the region, in case $T$.

424 annulata was only recently herein introduced and if the local vectorial competence of $H$.

425 dromedarii was confirmed. Indeed, by creating new suitable habitats for $H$. dromedarii, the

426 expansion of arid areas due to climate change, may lead the infection to spread across North-

427 Western Nigeria, together with its presumable vector.

428 In Mauritania, H. dromedarii was proposed as the natural vector of T. annulata [68-70],

429 although it was also noticed that the serological prevalence in cattle increased in areas with

430 more diversified tick fauna, suggesting the potential implication of other species such as

431 Rhipicephalus evertsi evertsi $[68,69]$. This tick species was previously recorded in cattle in

432 two surveys from Sokoto State (with a prevalence of $2.6 \%$ and $5.5 \%$, respectively) [19, 21],

433 as well as from south-eastern (i.e. Oyo State) [78] and eastern regions (i.e. Adamawa State)

434 [79]. Therefore, the potential participation of Rh. e. evertsi in the epidemiology of T. annulata

435 in North-Western Nigeria could not be excluded and should be further investigated. Future

436 studies aiming to assess the occurrence of this tick species in Zamfara, are also advisable,

437 especially considering that, besides Sokoto, the latter borders also with the States of Katsina

438 and Kaduna, where Rh e. evertsi was recently identified in horses [80].

439 Like in this study, a few $(\mathrm{n}=2 / 30 ; 7 \%)$ partially fed $H$. rufipes ticks collected from cattle in the

440 Gorgol region in Mauritania, were also found positive for T. annulata at PCR, although at a

441 much lower prevalence compared to H. dromedarii $(\mathrm{n}=17 / 30 ; 57 \%)$ [70]. The vectorial 
442 competence of $H$. rufipes has indeed been demonstrated experimentally through studies on

443 cattle, in which transstadial transmission (i.e. from nymph to adult) occurred [81].

444 Nevertheless, this tick is regarded as an unlikely vector of T. annulata in field conditions [81],

445 since its immature stages usually parasitise ground-feeding birds [82]. Nymphal stages of

446 Hyalomma impeltatum were also showed to transmit T. annulata in experimental conditions

447 in Sudan [83]. Yet, this tick species is not considered a relevant vector of T. annulata either

448 [83], because its immature stages mostly feed on rodents, hares and birds [84].

449 Although our study detected T. annulata DNA in several Hyalomma species, all but one

450 specimen were partially fed or near replete, thus results cannot be interpreted as an indication

451 of vector competence. Moreover, the not infrequent detection of T. annulata DNA in multiple

452 ticks infesting the same individual cow underlines also the possible presence of this pathogen

453 in the bovine blood. Interestingly, the only unfed tick specimen that was found positive in this

454 survey was a male $H$. dromedarii, this being a further suggestion of the possible implication

455 of this species in the transmission of T. annulata in the region. The state of repletion of male

456 specimens of this tick is indeed identifiable through the examination of the position of the

457 subanal plates (in fed individuals they protrude beyond the posterior margin of the body) [51].

460 This study confirmed the presence of several tick species in North-Western Nigeria, most of

461 which were previously documented in cattle and camels in Northern Nigeria and provides the

462 first locality records for Zamfara State. The preponderance of $H$. dromedarii in cattle from

463 Sokoto rather than Zamfara, coupled with the time of the year when the sampling took place

464 (i.e. late dry season), highlights the suitability of this tick species for the arid environments of

465 the Sahelian belt [51]. The potential expansion of drylands favoured by the ongoing climatic

466 changes may potentially lead $H$. dromedarii to become more prevalent in the future in 
467 neighbouring southbound States (e.g. Zamfara, Kebbi and Kaduna). This warrants constant

468 monitoring of the tick fauna infesting livestock of great economic relevance in Northern and

469 Central Nigeria, such as ruminants and camels, including also cattle newly introduced from

470 Niger or Chad for commercial purposes.

471 The occurrence of $H$. turanicum, recorded for the first time in Nigeria indicates a distribution

472 of this tick beyond Northern Africa. Further studies aiming to better understand its occurrence

473 and potential vectorial role, in SSA and Nigeria, would be advisable.

474 We also presented strong evidence for the presence of T. annulata in North-Western Nigeria

475 and demonstrate its carriage by a range of primarily fed ticks collected off cattle. These

476 observations pave the way for further epidemiological studies to clarify the transmission of $T$.

477 annulata infections in the region and demand veterinary investigation of their impact on

478 livestock well-being and productivity. Our findings and the existing literature suggest $H$.

479 dromedarii as most probable vector in the area, although other species (e.g. Rh. e. evertsi)

480 may also participate in the epidemiology of $T$. annulata infection.

481 Whether this infection has been newly introduced in Nigeria through trade cattle from

482 Sahelian countries or whether it has long been endemically established in the local Zebu

483 population, its presence represents a serious threat to the development of the livestock sector

484 in North-Western Nigeria, given the severity of tropical theileriosis in crossbreed and exotic

485 cattle species. For these reasons, this study's findings need to be disseminated among

486 veterinary authorities and livestock professionals in the country, to raise awareness on this

487 tick-borne infection.

\section{Declarations}




\section{Ethics approval and consent to participate}

491 Approval for this study was obtained from the ethics committee of the University of Salford,

492 Manchester, UK. At each study site in Anka (Zamfara), cattle owners (i.e. Fulani pastoralists)

493 were approached and informed about the aims and methods of the study before being asked

494 for informed consent. In northern Sokoto, the project was first discussed with Miyetti Allah,

495 the local Fulani association that manages cattle markets in the region. Subsequently, cattle

496 sellers in these markets were approached as described above and their informed consent

497 requested.

\section{Competing interests}

499 The authors declare that they have no competing interests. The sponsor had no role in the

500 study design, data collection and analysis, manuscript preparation and decision to publish.

\section{Authors' contributions}

502 AHM, VL, BMA, KJB and RJB conceived of the study and participated in its design. AHM,

503 BMA, VL and RJB coordinated the field activities and tick collection. AHM and VL

504 performed tick identification. AHM, BMA and RJB carried out the molecular analysis. VL

505 and RJB took care of the statistical analysis. AHM, VL and RJB wrote the paper. All authors

506 read and approved the final manuscript.

\section{Funding}

508 The Nigerian Petroleum Technology Development Fund provided funding to support HAM's

509 Master's studies, including this research and its field activities.

\section{Acknowledgements}

511 We thank the Nigerian Petroleum Technology Development Fund for funding HAM's MSc

512 studies at the University of Salford, during which this research was performed. We also

513 express appreciation to Adamu Samaila and his team for helping with the community 
514 sensitisation and sample collection. We are also grateful to all local authorities, cattle keepers

515 and sellers involved in this study for their kind collaboration. Fabio Di Chio is also thanked

516 for his kind assistance with preparation of the Figure.

517

518 Authors' information

519 AHM and VL contributed equally to this article.

520

521

522

523

524

525

526

527

528

529

530

531

532

533

534

535

536 References 
1. Uilenberg G. International collaborative research: significance of tick-borne haemoparasitic diseases to world animal health. Vet Parasitol. 1995;57:19-41. Suppl:3-14.

3. Minjauw B, McLeod A. Tick-borne diseases and poverty: The impact of ticks and tick-borne diseases on the livelihoods of small-scale and marginal livestock owners in India and eastern and southern Africa. Research Report, DFID Animal Health Programme. Centre for Tropical Veterinary Medicine, University of Edinburgh. perspective. Trend Parasitol. 2012;28:437-46.

5. FAO. Africa Sustainable Livestock 2050. Transforming livestock sector. Nigeria. What do long-term projections say? 2019. http://www.fao.org/inaction/as12050/countries/nga/en/. Accessed 23 Oct 2020.

6. World Bank, Livestock Productivity and Resilience Support Project (P160865) 2017. http://documents.worldbank.org/curated/en/479121500403272629/pdf/ITM00184P160865-07-18-2017-1500403268591.pdf. Accessed 23 Oct 2020. public health and veterinary significance in Nigeria. Trop Med Infect Dis. 2018;3:3. 
9. Kamani J, Apanaskevich D, Gutiérrez R, Nachum-Biala Y, Baneth G, Harrus S.

561

562

563

564

565

566

567

568

569

570

571

572

573

574

575

576

577

578

579

580

581

582
Morphological and molecular identification of Rhipicephalus (Boophilus) microplus in

Nigeria, West Africa: a threat to livestock health. Exp Appl Acarol. 2017;73:283-96.

10. Opara MN, Ezeh NO. Ixodid ticks of cattle in Borno and Yobe states of Northeastern

Nigeria: breed and coat colour preference. Anim Res Int. 2011;8:1359-65.

11. Musa HI, Jajere SM, Adamu NB, Atsanda NN, Lawal JR, Adamu SG, et al.

Prevalence of tick infestation in different breeds of cattle in Maiduguri, Northeastern

Nigeria. Bangl J Vet Med. 2014;12:161-6.

12. Eyo JE, Ekeh FN, Ivoke N, Atama CI, Onah IE, Ezenwaji NE, et al. Survey of tick infestation of cattle at four selected grazing sites in the tropics. Glob Vet. 2014;12:479-86.

13. Dipeolu OO. The incidence of ticks of Boophilus species on cattle, sheep and goats in Nigeria. Trop Animal Health Prod. 1975;7:35-9.

14. Mohammed AN. The seasonal incidence of ixodid ticks of cattle in Northern Nigeria. Bull Anim Health Prod Afr. 1977;25:273-93.

15. Iwuala MOE, Okpala I. Studies on the ectoparasitic fauna of Nigerian livestock I: types and distribution patterns on hosts. Bull Anim Health Prod Afr. 1978;16:339-49.

16. Bayer W, Maina JA. Seasonal pattern of tick load in Bunaji cattle in the subhumid zone of Nigeria. Vet Parasitol. 1984;15:301-7.

17. Awogbade M. Fulani pastoralism and the problems of the Nigerian Veterinary Service. Afr Aff. 1979;78:493-506.

18. Iwuala MOE, Okpala I. Studies on the ectoparasitic fauna of Nigerian livestock I: types and distribution patterns on hosts. Bull Anim Health Prod Afr. 1978;16:339-49. 
19. Lawal MD, Fabiyi JP, George BDJ, Adamu Y, Kabir A, Alayande MO, et al.

584 Preliminary study on the Monthly dynamics of cattle tick infestation in Sokoto, north western Nigeria. Nig J Anim Prod. 2017;44:296-300.

20. Opara MN, Abdu Y, Okoli IC. Survey of ticks of Veterinary Importance and Tickborne Protozoa of Cattle grazed in very hot months in Sokoto Municipality, Nigeria. Int J Agric Rural Dev. 2005;6;167-74.

21. Okwuonu ES, Bala AY, Ikpeze OO. Ticks infestation of Zebu cattle crosses in Sokoto, Nigeria. The Bioscientist. 2017;5:50-6.

22. Abdullahi YA, Magami IM, Audu A, Mainasara MM. Prevalence of Ticks on Camels and Cattle Brought to Dodoru Market Kebbi State, Nigeria. Path of Science. 2018;4: $3001-4$.

23. Leeflang P, Ilemobade AA. Tick-borne diseases of domestic animals in northern Nigeria. I. Historical review, 1923-1969. Trop Anim Health Prod. 1977;9:147-52.

24. Leeflang P, Ilemobade AA. Tick-borne diseases of domestic animals in northern Nigeria. II. Research summary, 1966 to 1976. Trop Anim Health Prod. 1977;9:211-8.

25. Akinboade OA, Dipeolu OO. Comparison of blood smear and indirect fluorescent antibody techniques in detection of haemoparasite infections in trade cattle in Nigeria. Vet Parasitol. 1984;14:95-104.

26. Saidu SN, Abdulkadir IA, Akerejola OO. Theileria mutans infection in Nigerian cattle. Trop Anim Health Prod. 1984;16:149-52.

27. Dipeolu OO, Amoo A. The presence of kinetes of a Babesia species in the haemolymph smears of engorged Hyalomma ticks in Nigeria. Vet Parasitol. $1984 ; 17: 41-6$. 
606

607

608

609

610

611

612

613

614

615

616

617

618

619

620

621

622

623

624

625

626

627

628

629

28. Kamani J, Sannusi A, Egwu O, Dogo G, Tanko T, Kemza S et al. Prevalence and significance of haemoparasitic infections of cattle in north-central, Nigeria. Vet World. 2010;3:445-8.

29. Obi TU. Survey of the incidence of anaplasmosis among Nigerian Zebu trade cattle. Trop Anim Health Prod. 1978;10:87-90.

30. Ajayi SA, Fabi JP, Umo I. Clinical bovine anaplasmosis and babesiosis in Fresian cattle: an outbreak in Nigeria and its control. Wld Anim Rev. 1982;6:41.

31. Ajayi SA, Dipeolu OO. Prevalence of Anaplasma marginale, Babesia bigemina and B. bovis in Nigerian cattle using serological methods. Vet Parasitol. 1986;22:147-9.

32. Elelu N, Bankole AA, Musa RJ, Odetokun IA, Rabiu M, Biobaku KT, et al. Serospatial epidemiology of zoonotic Coxiella burnetii in a cross section of cattle and small ruminants in northern Nigeria. PLoS One. 2020 Oct 19;15(10):e0240249.

33. Elelu N, Ferrolho J, Couto J, Domingos A, Eisler MC. Molecular diagnosis of the tick-borne pathogen Anaplasma marginale in cattle blood samples from Nigeria using qPCR. Exp Appl Acarol. 2016;70:501-10.

34. Lorusso V, Wijnveld M, Majekodunmi AO, Dongkum C, Fajinmi A, Dogo AG, et al. Tick-borne pathogens of zoonotic and veterinary importance in Nigerian cattle. Parasit Vectors. 2016;9:217.

35. Hector E, Elelu N, Ferrolho J, Couto J, Sanches G, Antunes S, Domingos A, Eisler M. PCR detection of Ehrlichia ruminantium and Babesia bigemina in cattle from Kwara State, Nigeria: unexpected absence of infection. Parasitol Res. 2019;118:1025-9.

36. Ogo N, de Mera I, Galindo R, Okubanjo O, Inuwa H, Agbede R et al. Molecular identification of tick-borne pathogens in Nigerian ticks. Vet Parasitol. 2012;187:572 7. 
630 37. Lorusso V, Gruszka KA, Majekodunmi A, Igweh A, Welburn SC, Picozzi K.

631 Rickettsia africae in Amblyomma variegatum ticks, Uganda and Nigeria. Emerg Infect

632 Dis. $2013 ; 19: 1705-7$.

633 38. ECOWAS - SWAC/OECD. Livestock and regional market in the Sahel and West

634 Africa. Potentials and challenges. 2008.

635 https://www.oecd.org/swac/publications/41848366.pdf. Accessed 30 Oct 2020.

636 39. Ebele NE, Emodi NV. Climate change and its impact in Nigerian economy. J Sci Res

$637 \quad$ Report. 2016;10:1-13.

638 40. FAO. Irrigation in Africa in figures - AQUASTAT Survey 2005. Nigeria Irrigation in 639 Africa in figures AQUASTAT Survey - 2005 Edited by Karen Frenken. FAO Water $640 \quad$ reports, 29. Rome. 2005; 433-46.

641 41. Fishwick RW. Sahel and Sudan zone of northern Nigeria, north Cameroons and the 642 Sudan. In: Kaul RN, editor. Afforestation in Arid Zones. Dordrecht: Springer; 1970. $643 \quad 59-85$.

644 42. Abdulkadir TS, Salami AW, Aremu AS, Ayanshola AM, Oyejobi DO. Assessment of 645 neural networks performance in modelling rainfall amounts. J Res Forest Wildl $646 \quad$ Environ. 2017;9:12-22.

647 43. Haider H. Climate change in Nigeria: Impacts and responses. K4D Helpdesk Report 648 675. Brighton, UK: Institute of Development Studies. 2019;1-38.

649 44. Ogden NH, Lindsay LR. Effects of Climate and Climate Change on Vectors and 650 Vector-Borne Diseases: Ticks Are Different.Trends Parasitol. 2016;32:646-56.

651 45. Atedhor GO. Agricultural vulnerability to climate change in Sokoto State Nigeria. 652 African J Food Agric Nutr Dev. 2015;15:9855-71. 


\section{3}

654

655

656

657

658

659

660

661

662

663

664

665

666

667

668

669

670

671

672

673

674

675

46. Chukwuji NC, Aliyu GT, Sule S, Yusuf Z, Zakariya J. Awareness, access and utilization of information on climate change by farmers in Zamfara State, Nigeria. Libr Philos Pract. 2019;1-24.

47. National Bureau of Statistics. Poverty and Inequality in Nigeria: Executive Summary -2019. 2019; 1-25. National Bureau of Statistics, Plot 762, IndependenceAvenue, Central Business District, Abuja, FCT, Nigeria. https://nigerianstat.gov.ng/elibrary?queries[search]=poverty. Accessed 23 Oct 2020.

48. Bello M, Anka A, Yusuf A. Declining Grazing Resources: the Stateand Future of The Livestock Economy in Zamfara. IOSR Journal Of Humanities And Social Science. 22: 61-72.

49. Keay R. An example of Sudan Zone vegetation in Nigeria. J Ecol. 1949;37:335-64.

50. Baker MK, Ducasse FB. Tick infestation of livestock in Natal. The predilection sites and seasonal variations of cattle ticks. J S Afr Vet Assoc. 1967;38:447-53.

51. Walker AR, Bouattour A, Camicas JL, Estrada-Peña A, Horak IG, Latif A, et al. Ticks of domestic animals in Africa, A guide to identification of species. Edinburgh, UK: Bioscience Reports; 2014.

52. Guy EC, Stanek G. Detection of Borrelia burgdorferi in patients with Lyme disease by the polymerase chain reaction. J Clin Pathol 1991;44:610-1.

53. Simpson V, Panciera R, Hargreaves J, McGarry J, Scholes S, Bown K et al. Myocarditis and myositis due to infection with Hepatozoon species in pine martens (Martes martes) in Scotland. Vet Rec. 2005;156:442-6.

54. Salih D, Hassan S, El Hussein A, Jongejan F. Preliminary survey of ticks (Acari: Ixodidae) on cattle in northern Sudan. Onderstepoort J Vet Res. 2004;71;319-26. 
676

677

678

679

680

681

682

683

684

685

686

687

688

689

690

691

692

693

694

695

696

697

698

699

55. Silatsa B, Simo G, Githaka N, Mwaura S, Kamga R, Oumarou F et al. A comprehensive survey of the prevalence and spatial distribution of ticks infesting cattle in different agro-ecological zones of Cameroon. Parasit Vect. 2019;12:489.

56. Lawal MD, Ameh IG, Ahmed A. Some ectoparasites of Camelus dromedarius in Sokoto, Nigeria. Nig J Entomol 2007;4:143-8.

57. Onyiche TE, Răileanu C, Tauchmann O, Fischer S, Vasić A, Schäfer M, et al. Prevalence and molecular characterization of ticks and tick-borne pathogens of onehumped camels (Camelus dromedarius) in Nigeria. Parasit Vectors. 2020;13:428.

58. Boka O, Achi L, Adakal H, Azokou A, Yao P, Yapi Y, et al. Review of cattle ticks (Acari, Ixodida) in Ivory Coast and geographic distribution of Rhipicephalus (Boophilus) microplus, an emerging tick in West Africa. Exp Appl Acarol. $2017 ; 71: 355-369$.

59. Nelson KS, Bwala DA, Nuhu EJ. The Dromedary Camel; A Review on the Aspects of History, Physical Description, Adaptations, Behavior/Lifecycle, Diet, Reproduction, Uses, Genetics and Diseases. Nig Vet J. 2015;36:1299-1317.

60. Kabore H, Salembere M, Tamboura H. Seasonal variation of ticks on cattle in Burkina Faso. Ann N Y Acad Sci. 1998;849:398 -401.

61. Sungirai M, Abatih E, Moyo D, Clercq P, Madder M. Shifts in the distribution of ixodid ticks parasitizing cattle in Zimbabwe. Med Vet Entomol. 2016;31:78-87.

62. Potgieter FT. Epizootiology and control of anaplasmosis in South Africa. J S Afr Vet Assoc. 1979; 50:367-72.

63. Blouin EF, van Rensburg L. An ultrastructural study of the development of Babesia occultans in the salivary glands of adult Hyalomma marginatum rufipes.

Onderstepoort J Vet Res.1988; 55: 93-100. 
64. Kamani J, Baneth G, Apanaskevich DA, Mumcuoglu KY, Harrus S. Molecular detection of Rickettsia aeschlimannii in Hyalomma spp. ticks from camels (Camelus dromedarius) in Nigeria, West Africa. Med Vet Entomol. 2015; 29:205-9. pathology of sweating sickness in cattle. Onderstepoort J Vet Res. 1987;54:45-8. Hyalomma marginatum complex transported by migratory birds into Central Europe. Ticks Tick Borne Dis. 2014;5:489 -93. status of tropical theileriosis in Northern Africa: A review of recent epidemiological investigations and implications for control. Transb Emerg Dis. 2020;67(S1):8-25. Theileria annulata in Mauritania. Rev Elev Med Vet Pays Trop. 1990;43:489-90 [Article in French]. theileriosis caused by Theileria annulata in Mauritania, Subsaharian West Africa. Rev Elev Med Vet Pays Trop. 1994;47(2):147-55 [Article in French]. annulata by the PCR in ticks (Acari:Ixodidae) collected from cattle in Mauritania. Exp Appl Acarol. 1997;21:279-91. breeding in dromedary camels: Insights from pastoralists in some selected villages of the Nigeria-Niger corridor. Livestock Research for Rural Development. 2011;23. http://www.lrrd.org/lrrd23/8/abdu23178.htm. Accessed 20 Apr 2020. 
72. Oyewusi IK, Ganiyu IA, Akande FA, Takeet MI, Anifowoshe IO, Famuyide IM, et al.

725 Assessment of ticks on cattle entering Nigeria through a major trans-boundary animal route in Ogun State. Bull Anim Health Prod Afr. 2015;63:369-77. exchange and sub-structuring in Theileria annulata populations. Mol Biochem Parasitol. 2007;154:170-80.

74. Bakheit MA, Latif AA. The innate resistance of Kenana cattle to tropical theileriosis (Theileria annulata infection) in the Sudan. Ann N Y Acad Sci. 2002;969:159-63. impact of tick-borne pathogen infection in Indian bovines is determined by host type but not the genotype of Theileria annulata. Infect Gen Evol 2019;75:103972.

76. Youssef SY, Yasien S, Mousa WM, Nasr SM, El-Kelesh EA, Mahran KM, et al. Vector identification and clinical, hematological, biochemical, and parasitological characteristics of camel (Camelus dromedarius) theileriosis in Egypt. Trop Anim Health Prod. 2015;47:649-56. Canine and ovine tick-borne pathogens in camels, Nigeria. Vet Parasitol.

79. Pukuma SM, James-Rugu NN, Sale M. A study on tick borne infections of cattle in Yola locality of Adamawa State. Afr J Agri Res. 2011;6:6208-11. 
in equines and ticks in Nigeria: prevalence and risk factors analysis. Parasitology. 2020;147:1238-48.

751

81. Jongejan F, Morzaria SP, Mustafa OE, Latif AA. Infection rates of Theileria annulata

752 in the salivary glands of the tick Hyalomma marginatum rufipes. Vet Parasitol.

753 $1983 ; 13: 121-6$.

82. Van Niekerk J, Fourie LJ, Horak IG. Birds as hosts of immature ixodid ticks in Free State Province, South Africa. Onderstepoort J Vet Res. 2006;73:123-30. annulata by Hyalomma ticks in the Sudan. Vet Q. 1983;5:112-3. 
bioRxiv preprint doi: https://doi.org/10.1101/2020.11.10.376624; this version posted November 10,2020 . The copyright holder for this preprint (which was not certified by peer review) is the author/funder, who has granted bioRxiv a license to display the preprint in perpetuity. It is made available under aCC-BY-NC-ND 4.0 International license.

774 Table 1. Number of animals surveyed, number of ticks collected and mean tick loads.

\begin{tabular}{|c|c|c|c|c|c|c|c|c|}
\hline \multirow[b]{2}{*}{ State } & \multirow{2}{*}{$\begin{array}{c}\text { Local } \\
\text { Government } \\
\text { Area } \\
\text { (LGA) }\end{array}$} & \multirow{2}{*}{ Village } & \multirow{2}{*}{$\begin{array}{c}\text { No. of } \\
\text { Cattle } \\
\text { sampled }\end{array}$} & \multicolumn{3}{|c|}{ Ticks collected } & \multicolumn{2}{|c|}{$\begin{array}{c}\text { Mean tick } \\
\text { count/animal } \pm \mathrm{SE}\end{array}$} \\
\hline & & & & Males & Females & TOTAL & $\begin{array}{l}\text { Village } \\
\text { level }\end{array}$ & $\begin{array}{l}\text { State } \\
\text { level }\end{array}$ \\
\hline \multirow{5}{*}{ Zamfara } & \multirow{5}{*}{ Anka } & Anka & 16 & 36 & 6 & 42 & $\begin{array}{l}2.62 \pm \\
1.67\end{array}$ & \multirow{5}{*}{$\begin{array}{l}3.0 \pm \\
2.28^{*}\end{array}$} \\
\hline & & Kwaye & 14 & 22 & 14 & 36 & $\begin{array}{l}2.57 \pm \\
2.31\end{array}$ & \\
\hline & & Kwakwalwa & 11 & 28 & 15 & 43 & $\begin{array}{l}3.9 \pm \\
1.87\end{array}$ & \\
\hline & & Gema & 15 & 32 & 14 & 46 & $\begin{array}{l}3.06 \pm \\
2.12\end{array}$ & \\
\hline & & Abara & 24 & 56 & 17 & 73 & $\begin{array}{l}3.04 \pm \\
2.88\end{array}$ & \\
\hline $\begin{array}{l}\text { Sub- } \\
\text { total }\end{array}$ & & & 80 & 174 & 66 & 240 & & \\
\hline \multirow{3}{*}{ Sokoto } & Sokoto North & Kara & 13 & 18 & 36 & 54 & $\begin{array}{c}4.15 \pm \\
4.20\end{array}$ & \multirow{3}{*}{$\begin{array}{l}3.91 \pm \\
3.15^{*}\end{array}$} \\
\hline & Wurno & Achida & 20 & 40 & 54 & 94 & $\begin{array}{l}4.70 \pm \\
3.87\end{array}$ & \\
\hline & Illela & Illela & 32 & 29 & 77 & 106 & $\begin{array}{c}3.31 \pm \\
1.91\end{array}$ & \\
\hline $\begin{array}{l}\text { Sub- } \\
\text { total }\end{array}$ & & & 65 & 87 & 167 & 254 & & \\
\hline & TOTAL & & 145 & 261 & 233 & 494 & & \\
\hline
\end{tabular}


bioRxiv preprint doi: https://doi.org/10.1101/2020.11.10.376624: this version posted November 10.2020 . The copvriaht holder for this preprint (which was not certified by peer review) is the author/funder, who has granted bioRxiv a license to display the preprint in perpetuity. It is made available under aCC-BY-NC-ND 4.0 International license.

776 Table 2. Cumulative counts, prevalence, number of males and females, and male: female ratio

777 of ticks identified.

\begin{tabular}{|c|c|c|c|c|c|c|}
\hline State & Tick species & Total & $\begin{array}{c}\text { Mean Prevalence \% } \\
\text { (95\% confidence } \\
\text { interval) }\end{array}$ & Males & Females & $\begin{array}{c}\text { Male : Female } \\
\text { ratio }\end{array}$ \\
\hline \multirow{9}{*}{ Zamfara } & Hyalomma rufipes & 183 & $76.2(70.3-81.5)$ & 135 & 48 & $2.8: 1$ \\
\hline & Hyalomma truncatum & 18 & $7.5(4.5-11.6)$ & 16 & 2 & $8: 1$ \\
\hline & Hyalomma impeltatum & 14 & $5.8(3.2-9.6)$ & 6 & 8 & $1: 1.3$ \\
\hline & Hyalomma impressum & 9 & $3.7(1.7-7.0)$ & 8 & 1 & $8: 1$ \\
\hline & Amblyomma variegatum & 7 & $2.9(1.2-5.9)$ & 7 & 0 & $7: 0$ \\
\hline & Hyalomma dromedarii & 6 & $2.5(0.9-5.3)$ & 1 & 5 & $1: 5$ \\
\hline & Hyalomma marginatum & 1 & $0.4(0.0-2.3)$ & 1 & 0 & $1: 0$ \\
\hline & Hyalomma turanicum & 1 & $0.4(0.0-2.3)$ & 0 & 1 & $0: 1$ \\
\hline & Rhipicephalus (Boophilus) decoloratus & 1 & $0.4(0.0-2.3)$ & 0 & 1 & $0: 1$ \\
\hline Total & & 240 & & 174 & 66 & $2.6: 1$ \\
\hline \multirow{6}{*}{ Sokoto } & Hyalomma dromedarii & 111 & $43.7(37.5-50.0)$ & 47 & 64 & $1: 1.4$ \\
\hline & Hyalomma impeltatum & 93 & $36.6(30.7-42.9)$ & 29 & 64 & $1: 2.2$ \\
\hline & Hyalomma truncatum & 27 & $10.6(7.1-15.1)$ & 7 & 20 & $1: 2.9$ \\
\hline & Hyalomma impressum & 15 & $5.9(3.3-9.5)$ & 0 & 15 & $0: 15$ \\
\hline & Hyalomma rufipes & 8 & $3.1(1.4-6.1)$ & 4 & 4 & $1: 1$ \\
\hline & & 254 & & 87 & 167 & $1: 1.9$ \\
\hline
\end{tabular}

778

779

780

781

782

783

784

785

786

787 
bioRxiv preprint doi: https://doi.org/10.1101/2020.11.10.376624; this version posted November $10,2020$. The copyright holder for this preprint (which was not certified by peer review) is the author/funder, who has granted bioRxiv a license to display the preprint in perpetuity. It is made available under aCC-BY-NC-ND 4.0 International license.

788 Table 3. Ticks screened and tested positive for the detection of Apicomplexan (i.e. Theileria

789 annulata) DNA.

\begin{tabular}{|c|c|c|c|c|}
\hline \multirow[b]{2}{*}{ Tick species } & \multicolumn{2}{|c|}{ Zamfara } & \multicolumn{2}{|c|}{ Sokoto } \\
\hline & $\begin{array}{c}\text { Proportion of } \\
\text { screened } \\
\text { ticks/total } \\
\text { (Percentage) }\end{array}$ & $\begin{array}{c}\text { Proportion of } \\
\text { positive ticks for } \\
\text { Theileria } \\
\text { annulata } \\
\text { (Prevalence) }\end{array}$ & $\begin{array}{c}\text { Proportion of } \\
\text { screened } \\
\text { ticks/total } \\
\text { (Percentage) }\end{array}$ & $\begin{array}{c}\text { Proportion of } \\
\text { positive ticks for } \\
\text { Theileria annulata } \\
\text { (Prevalence) }\end{array}$ \\
\hline H. rufipes & $\begin{array}{l}32 / 183 \\
(17 \%)\end{array}$ & $\begin{array}{c}1 / 32 \\
(3.1 \%)\end{array}$ & $\begin{array}{c}5 / 8 \\
(62.5 \%)\end{array}$ & $\begin{array}{c}2 / 5 \\
(40 \%)\end{array}$ \\
\hline H. truncatum & $\begin{array}{c}7 / 18 \\
(38.9 \%)\end{array}$ & $\begin{array}{l}0 / 7 \\
(0 \%)\end{array}$ & $\begin{array}{c}6 / 27 \\
(22.2 \%)\end{array}$ & $\begin{array}{c}3 / 6 \\
(50 \%)\end{array}$ \\
\hline $\begin{array}{c}H . \\
\text { impeltatum }\end{array}$ & $\begin{array}{c}5 / 14 \\
(35.7 \%)\end{array}$ & $\begin{array}{l}0 / 5 \\
(0 \%)\end{array}$ & $\begin{array}{c}38 / 93 \\
(40.9 \%)\end{array}$ & $\begin{array}{c}11 / 38 \\
(28.9 \%)\end{array}$ \\
\hline $\begin{array}{c}. \\
\text { impressum }\end{array}$ & $\begin{array}{c}2 / 9 \\
(22.2 \%)\end{array}$ & $\begin{array}{l}0 / 2 \\
(0 \%)\end{array}$ & $\begin{array}{c}7 / 15 \\
(46.7 \%)\end{array}$ & $\begin{array}{c}1 / 7 \\
(14.3 \%)\end{array}$ \\
\hline $\begin{array}{c}\text { A. } \\
\text { variegatum }\end{array}$ & $\begin{array}{c}3 / 7 \\
(42.9 \%)\end{array}$ & $\begin{array}{l}0 / 3 \\
(0 \%)\end{array}$ & 0 & - \\
\hline $\begin{array}{c}. \\
\text { dromedarii }\end{array}$ & $\begin{array}{c}2 / 6 \\
(33.3 \%)\end{array}$ & $\begin{array}{c}1 / 2 \\
(50 \%)\end{array}$ & $\begin{array}{c}49 / 111 \\
(44.14 \%)\end{array}$ & $\begin{array}{c}12 / 49 \\
(24.5 \%)\end{array}$ \\
\hline $\begin{array}{c}H . \\
\text { marginatum }\end{array}$ & $\begin{array}{c}1 / 1 \\
(100 \%)\end{array}$ & $\begin{array}{l}0 / 1 \\
(0 \%)\end{array}$ & 0 & - \\
\hline H. turanicum & $1 / 1$ & $0 / 1$ & 0 & - \\
\hline
\end{tabular}


bioRxiv preprint doi: $\mathrm{https}$ //doi.org/10.1101/2020.11.10.376624; this version posted November 10,2020 . The copyright holder for this preprint (which was not certified by peer review) is the author/funder, who has granted bioRxiv a license to display the preprint in perpetuity. It is made available under aCC-BY-NC-ND 4.0 International license.

\begin{tabular}{|c|c|c|c|c|}
\hline & $(100 \%)$ & $(0 \%)$ & & \\
\hline Rh. (Bo.) & $1 / 1$ & $0 / 1$ & 0 & - \\
decoloratus & $(100 \%)$ & $(0 \%)$ & & $\mathbf{2 9 / 1 0 5}$ \\
\hline \multirow{2}{*}{ TOTAL } & $\mathbf{5 4 / 2 4 0}$ & $\mathbf{2 / 5 4}$ & $\mathbf{1 0 5 / 2 5 4}$ & $\mathbf{( 2 7 . 6 \% ) *}$ \\
& $\mathbf{( 2 2 . 5 \% )}$ & $(\mathbf{3 . 7 \%})^{*}$ & $\mathbf{( 4 1 . 3 \% )}$ & \\
\hline
\end{tabular}

790

$791 *$ Statistically significant difference $(\mathrm{P}<0.001)$ between infection rates.

792

793

794

795

796

797

798

799

800

801

802

803

804

805

806

807 


\section{8}

\section{Figure 1. Tick species encountered in this survey.}

810 From top to bottom: Hyalomma dromedarii (I): adult male, dorsal and ventral view (I, a-b),

811 and adult female, dorsal and ventral view (I, c-d); Hyalomma rufipes (II): adult male, dorsal

812 and ventral view (II, a-b), and adult female, dorsal and ventral view (II, c-d); Hyalomma

813 impeltatum (III): adult male, dorsal and ventral view (III, a-b), and adult female, dorsal and

814 ventral view (III, c-d); Hyalomma truncatum (IV): adult male, dorsal and ventral view (IV,

815 a-b), and adult female, dorsal and ventral view (IV, c-d); Hyalomma impressum (V): adult

816 male, dorsal and ventral view (V, a-b), and adult female, dorsal and ventral view (V, c-d);

817 Hyalomma marginatum (VI): adult male, dorsal and ventral view (VI, a-b); Hyalomma

818 turanicum (VII): adult female, dorsal and ventral view (VII, a-b); Amblyomma variegatum

819 (VIII): adult male, dorsal and ventral view (VIII, a-b); Rhipicephalus (Boophilus)

820 decoloratus (IX): adult female, dorsal and ventral view (IX, a-b), and details of the ventral

821 view of the mouthparts $(\mathbf{I X}, \mathbf{c})$ showcasing $3+3$ rows of hypostomal teeth and the

822 protuberance with pectinate setae on the internal margin of palp article I. Black bar $=1 \mathrm{~mm}$.

824

825

826

827

828

829

830

831 

